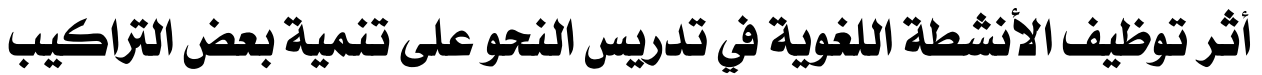

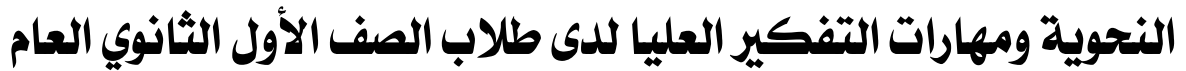

مستخلص بحث من رسالة ماجستير فى التربية تخصص (المناهج وطرق تلدريس اللغة العربية)

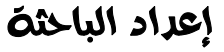

$$
\begin{aligned}
& \text { شيرين أبو العباس أحمد معوض }
\end{aligned}
$$

معلمة لغة عربية بمدرسة عزة زيلدان الرسمية للغات

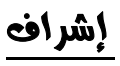

دامحمد أحمد عويس

مدرس المناهج وطرق تدريس اللغة العربية

كلية التربية ـ جامعة الفيوم تلمريس الفئم
أ.د/أمير صلاح الههواري

أستاذ المناهج وطرق تدريس اللغة العربية المساعد

كلية التزبية ـ جامعة الفيوم تلفئ الفربية

الماخصص

هدف البحث الحالي إلى التحقق من أثز توظيف الأنشطة اللغوبة في تدريس النحــو في تتمية بعض التر اكيب النحوية ومهار ات التفكير العليا لدى طلاب الـصف الأول الثانوي العام، وتكونت عينة البحث من (مب) طالبة مـن طالبـات الـصف الأول الثانوي العام بمدرسة عزة زيدان الرسمية للغات وتم إعداد اختبارين في التر اكيــب النحوية،ومهار ات التفكير العليا، وقائمة بمهار ات التفكير العليا و أسفرت النتائج عــن

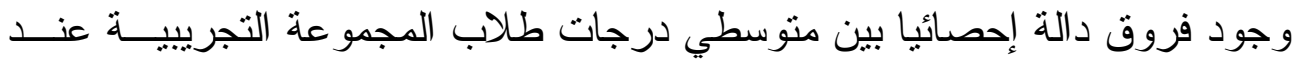
مستوى.، ا • في القياسين القبلي و البعدي للإختبار التحصيلي في التر اكيب النحوية، و اختبار مهار ات التفكير العليا لصالح القياس البعدي.

\title{
Abstract
}

The objective of the current research was to investigate the effect of the use of language activities in the teaching of grammar in the development of some grammatical structures and higher thinking skills among students in the first year of secondary education. The sample consisted of (35) female students of the first grade secondary school in the official school of Azza Zeidan The results revealed statistically significant differences between the mean scores of the experimental group students at..01 in the tribal and post-test scores in the grammatical structures and the test of higher thinking skills in favor of the dimensional measurement skills. 


\section{مقدمة البحث:}

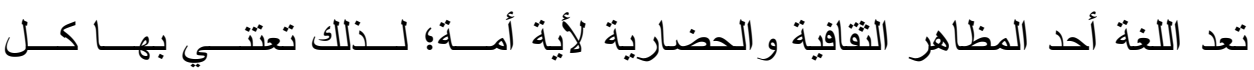
المجتمعات وخاصة تللك المجتمعات التي تعرف دور اللغة في تقدمها وازدهار هـــا، فاللغة تؤدي دور الايستهان به في الحفاظ على الهوية التقافية للـشعوب، وتعدــل

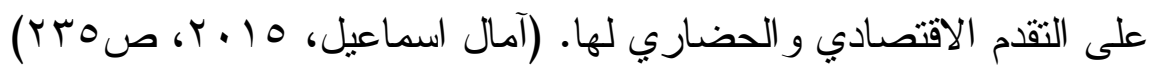
ويعد النحو العربي أحد فروع اللغة العربية، وهو علم يهدف إلى تقنـين القو اعــــ و التعميمات التي تصف تركيب الجمل،و الكلمات، وو عملهــا فــي حــال الاســتعمال

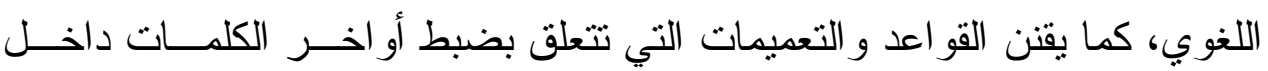
التركيب، علاوة على تحديد العلاقات القائمة بين الكلمات في الجمل و العبــار ات،

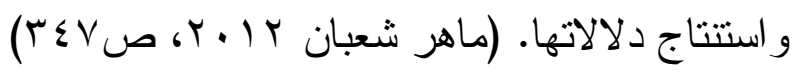

وتعتبر الأنشطة اللغوية من الوسائل الفعالة التي يستخدمها المعلـــم وتــستعين بهـــا المدرسة الحديثة في تحقيق أهداف تعليم اللغة العربية حيث أصبح مسلما به أن اللغة

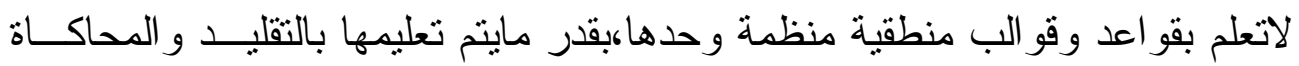

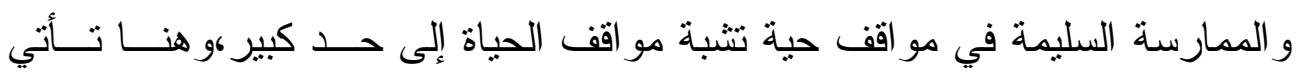

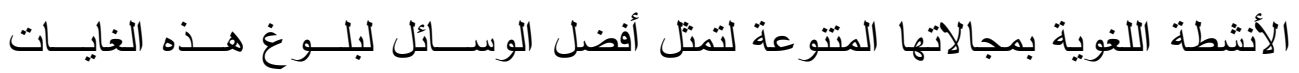

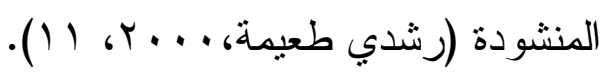

وفي ظلال النظريات الحديثة التي طر أت على العمليات المعرفية انبتقت الأنـشطة

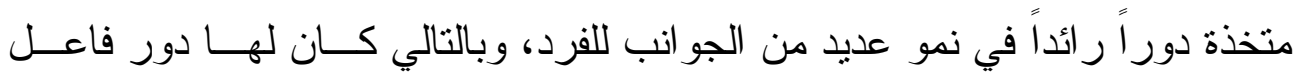
وحيوي في تتمية مهار ات اللغة المتعددة، وبشكل آخر فإن تعليم اللغة مــن خــله

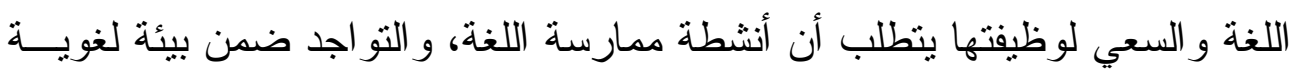

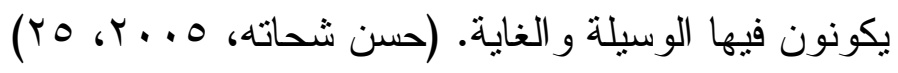

وتزتبط اللغة العربية بالتقكير ارتباطا وثيقا بالناحية العقلية عند الإنسان؛حيث إنهـا أداة العقل و الفهم و الاستتباط،كما أن هناك علاقة وثيقة بين اللغة العربيــة و التفكيـر 
عامة وبين التفكير اللغوي خاصة، وبين مدركات الإنسان العقلية، وذكائه، و أنمــاط تقكيره؛ حيث تذخل اللغة في أصل بناء الفكرة في ذهن الإنـسـان دخــو لا عــضـويا

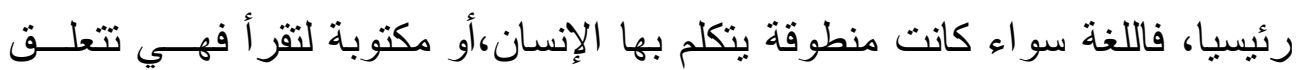

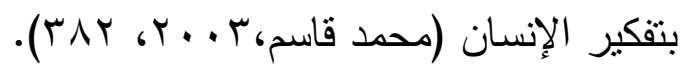

ويتضمن النحو العربي - بوصفه علماًا العديد من مهار ات التقكيــر العليــا مثــلـ: الاستقر اء و القياس، و التعليل. ولذا فعند تقنين قو اعد هذا العلم، قام النحـــاة بــصياغة دقيقة تقوم على الاستقر اء الدقيق، وأن يكفل لها التعليل، وأن تصبح كل قاعدة أصلاً

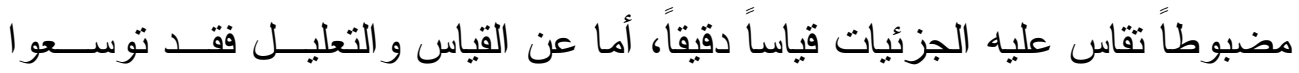

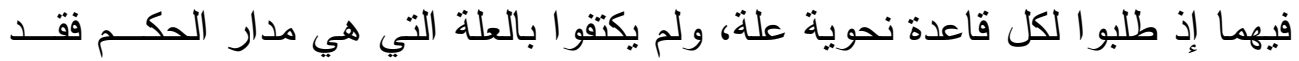

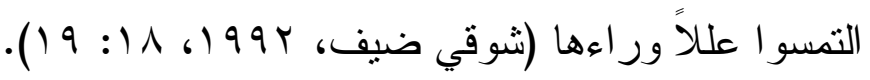

ومن مهار ات التفكير العليا في النحو مهارة التصنيف فيكاد يبدو في جميع تقسيمات النحو بدءاً بأقسام الكلم إلى المعرب و المبني، و الجامد و المشتق، و المجرد و المزيــــ، و الصحيح و المعتل و المقصور و المددود، و المتعدى و اللازم، إذ يتضح أنه لا يخلــو

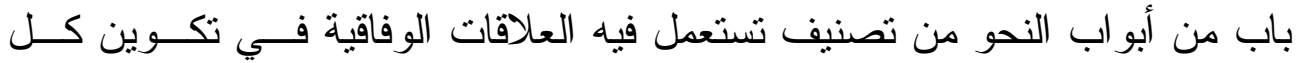
صنف على حدة، ثم تقوم العلاقات الخلافية بوظيفة التمييز و التفريق بين كل صنف

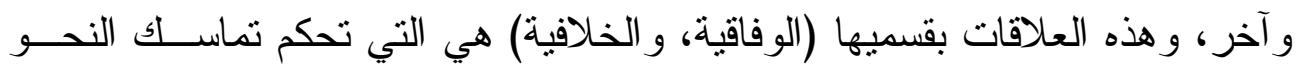

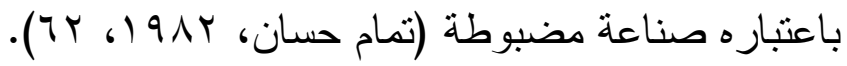

\section{الإحساس بمشكلة البحث:}

تنامى الإحساس بالمشكلة لاى الباحثة من خلا مايلي: ا-نتائج الدر اسات و البحوث السابقة في تعليم اللغة و التي أثنارت إلى ضـــف الطلاب في التز اكيب النحوية، ومعاناتهم في معرفتهم بالقو اعد النحوية. 
ץ- الإطلاع على توصيات بعض البحوث و الدر سات، و التي أكدت على أهمية

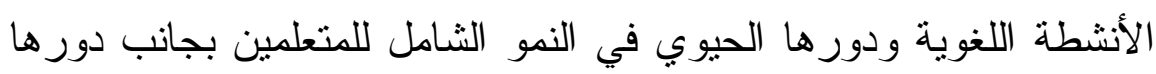
في تتمية فنون اللغة الأربعة.

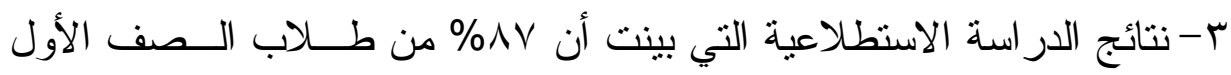
الثانوي لديهم قصور في مهار ات النحو وكذلك تدني في مهار ات التفكيـر العليا.

في ضوء ما سبق تبين للباحثة مدى حاجة طلاب الصف الأول الثانوي إلى تتميــة مهار ات النحو وكذلك مهار ات التفكير العليا؛ وهذا ما دفع الباحثة لقياس أثز نوظيف لئه الأنشطة اللغوية لتتمية مهار ات القو اعد النحوية،ومهار ات التفكير العليا لدى طــلاب الصف الأول الثانوي العام. مشكلة البحث و أسئلته: تتحدد مشكلة البحث في ضعف طلاب الصف الأول الثـانوي العــام فــي إتقــان مهار ات النحو وكذلك تدني مستو اهم في مهار ات التفكير العليا. ويمكن صياغة المشكلة في السؤال الرئيس الآتي: ماأثر توظيف الأنشطة اللغوية في تلريس النحو على تتميــة بعـض التراكيـب

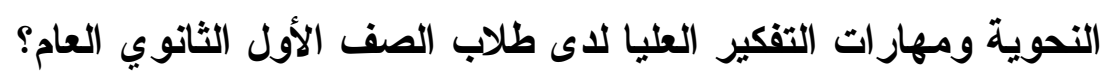

وينقرع من هذا السؤال الرئيس الأسئلة الفرعية التالية: ا - مالتز اكيب النحوية المناسبة التي يجب تتميتها لدى طلاب الصف الأول الثانوي

$$
\text { العام؟ }
$$

ץ- مامهار ات التفكير العليا في النحو التي يجب تتميتهـــا لطــلاب الــصف الأول

$$
\text { الثانوي العام ؟ }
$$

r- ماأثز توظيف الأنشطة اللغوية في تدريس النحو في تتميــة بعـض التز اكيــب النحوية ومهار ات التفكير العليا؟ 


\section{أهداف البحث: - 2 - 20}

\section{يرهف هذا البحث إلى:}

1 - التعرف على الأنشطة اللغوية المناسبة لطلاب الصف الأول الثانوي العام. r - إكساب الطلاب المهار ات النحوية من خلال التدريبات و التطبيقات اللغوية.

ب- التعرف على مهار ات التفكير العليا التي يجب تتميتهـــا لطــلاب الـــف الأول الثانوي العام.

ع - قياس أثز توظيف الأنشطة اللغوية في تدريس النحو في تتمية بعض التز اكيـب النحوية ومهار ات التقكير العليا لدى طلاب الصف الأول الثانوي العام. أهمية البحث:

1 - تتمية مهار ات التقكير العليا وقياسها لدى الطلاب من خــلال قائمـــة بمهــار ات التفكير r- يتيح الفرصة أمام الباحثين لإجر اء المزيد من الدر اسات و البحوث الممانلة فـي

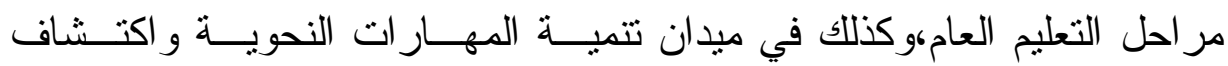
مشكلات بحثية بناء على نتائج البحث الحالي.

ب- إثر اء الحصيلة اللغوية لدى الطلاب؛ من خلا الأنشطة اللغوية و التفاعل معها.

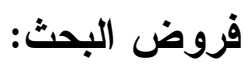

التزم البحث الحالي بالتحقق من صحة الفروض التالية:

توجد فروق ذا دلالة إحصائية بين متوسطي درجات طــلاب المجموعـــة التجريبية فى التطبيقين القبلي و البعدي لاختبار القو اعد النحويـــة لــصالح التطبيق البعدي. 
توجد فروق ذا دلالة إحصائية بين منوسطي درجات طلاب الصف الأول الثانوي العام عند مستوى..ه. في اختبار مهار ات التفكير العليا في النحو العربي في التطبيقين القبلي و البعدي لصالح التطبيق البعدي. توجد علاقة ارتباطية طردية بين أداء طلاب المجموعة التجريبيــة فـــي اختبار التز اكيب النحويةهوأدائهم في اختبار مهار ات التفكير العليا. حدود البحث:

$$
\text { اقتصر البحث الحالي على الحدود الآتية: }
$$

بعض المدارس الحكومية بمحافظة الفيوم التي سيتم اختيار ها عشو ائيا. بعض مهار ات التفكير العليا التي تتاسب طلاب الصف الأول الثانوي. الأنشطة اللغوية التي يمكن من خلالها تتمية مهار ات النحو.

$$
\text { أدوات البحث: }
$$

- قائمة بمهار ات التقكير العليا. - اختبار تحصيلي لقياس مهار ات النحو. - اختبار تحصيلي لقياس مهار ات التفكير العليا. مصطات البحث:

الأشثطة اللغوية: تعرف بأنها ألوان منتوعة من الممارسة التطبيقية لمهار ات اللغـــة

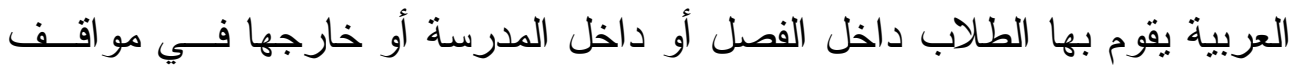
طبيعية تتطلب استماعاً أو كلاماً أو قر اعة أو كتابة، وذلك برغبتهم وبتوجيـهـ مــن فئن معلميهم من خلال جماعات أنشطة الإذاعةالمدرسـية أو الــصحافة المدرسـية أو أو

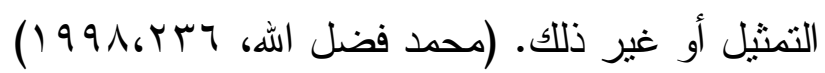


التز اكيب النحوية: "توخي معاني النحو،وترتيب الكلام وفق قو اعد تز اعي الــصو اب

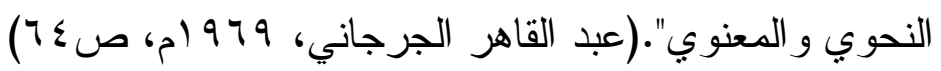

مهار ات التفكير: تعرف بأنها عمليات عقلية تتضمن كلاً من مهار ات التفكير الناقـد، و التفكير الإبداعي، وتتضمن الجانب الإنتاجي للتفكير الذي يشمل الفهم، و التفـسير، و الحكم الجيد على الأثياء، والتوصـل إلـى المعــاني ( Mosely and Others, .(2005: 162

\section{الإطار النظري والار اسات السابقة}

أولا- الأشطة اللغويـة:

1 - مفهوم الأنشطة اللغوية:

يعرف النشاط لغة: بأنه الممارسة الصادقة لعمل من الأعمال، ويقال نـشـط الرجــلـ إلى العمل ونحوه أي خف له وجد فيه وطابت نفسه له. (المعجــم الــوجيز، 2004، 616) أما من الناحية التربوية، فقد تعددت التعريفات على النحو التالي :

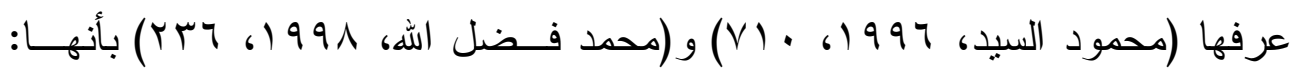
ألوان منتوعة من الممارسة التطبيقية لمهار ات اللغة العربية، يقوم بها التلاميذ داخل الفصل أو داخل المدرسة أو خارجها في مو اقف طبيعية تتطلب استماعا أو كلاما أو قر اعة أو كتابة، وذلك بر غبتهم وبتو جيه من معلميهم. r - فو ائد الأنشطة اللغوية: تتحدد فو ائد الأنشطة اللغوية في ثلاثة محاور، كما يلي: أ - الفوائد التربوية للأشطة اللغوية: تتضح أهمية الأنشطة اللغوية من الناحية التزبوية في مجموعة من النقاط، أهمها ما يلي: 
• إكساب المتعلم خبر ات لغوية تحقق نمو اشاملا معرفيا ومهاريا ووجدانيا. • تتمية المعارف و الحصيلة اللغوية بصورة تتجاوز حد التلقين.

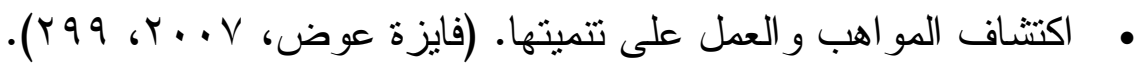
ب - الفوائد النفسية للأثشة اللغوية: - تعمل الأنشطة اللغوية على زيادة ثقة المتعلم بذاته من خلال إتاحة الفرصــة لــــ لمو اجهة الجمهور، وتمحو من المتعلم الثعور بالخوف و الرهبة، وتزيد من قدرته

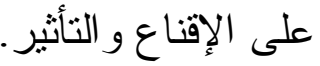

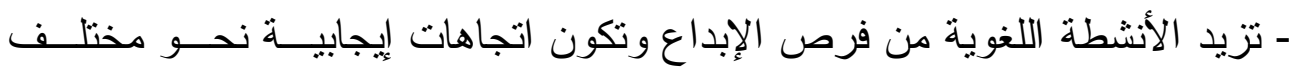

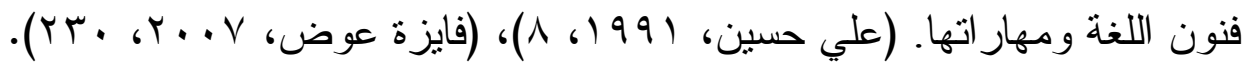
ج -الفوائد الاجتماعية للأشطة اللغوية: تعمل الأنشطة اللغوية على تتمية و إكـساب المتعلمـين العديــد مــن المهــار ات الاجتماعية منل: التعاون مع الآخرين - احتر ام مختلف الآر اء و الأفكار - مر اعــاة

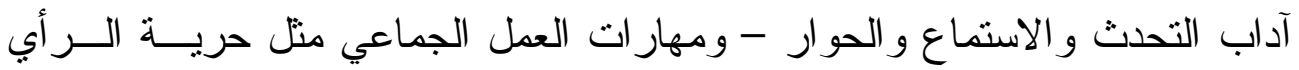

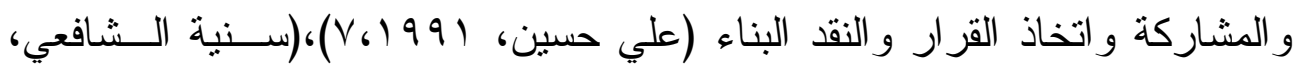

من أهم الأهداف التي تتحقق من خلال ممارسة الأنشطة اللغوية ما يلي: • تمكين التلاميذ من الانتفاع باللغة انتفاعا عمليا في مجالات التعبير الوظيفي و الإبداعي، ويتحقق ذلك بممارسة الحديث و الحو ار و المناقثات. • ت تـريب التلاميذ على استخدام اللغة استخداما صحيحا ناجحـــا فــي مواقــف الحياة العملية، وما تتطلبه هذه المو اقف. 


\section{• معالجة التلاميذ الذين يميلون إلى الانطو اء و العزلة.}

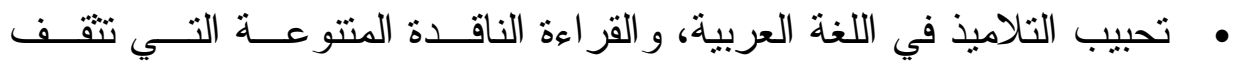
عقولهم وتهذب أذو اقهم.

• تمية المهار ات اللغوية لدى المتعلمين في مختلف فنون اللغـــة (الاســتماع،

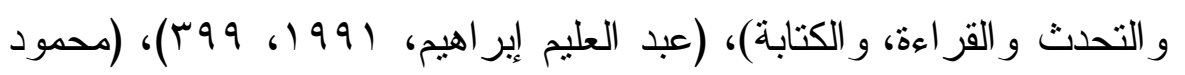

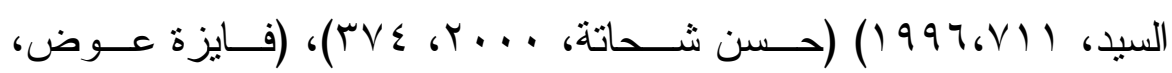

$$
\cdot(r M), r \cdot V
$$

ع - أسس ممارسة الأشطة اللغوية:

ممارسة الأنشطة دون إجبار للمتعلمين وفي جو من الحرية، و الديمقر اطية، وتباين الآر اء وتقدير رغبة الفرد وميوله.

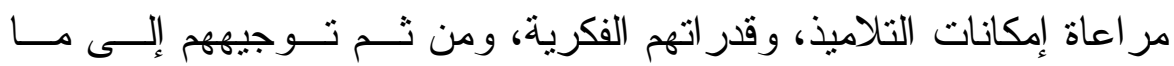

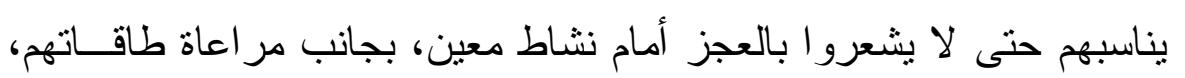
فلا يثقل عليهم بالاشتر اك في عدة أعمال مر هقة. تجري الأنشطة في مو اقف مشابهة للمو اقف الحياتية الطبيعية، بمعنى آخــر

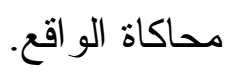

• أن تتضمن الأنشطة اللغوية نظاما للتقويم وتقديم التغذية الر اجعة و التعزيز.

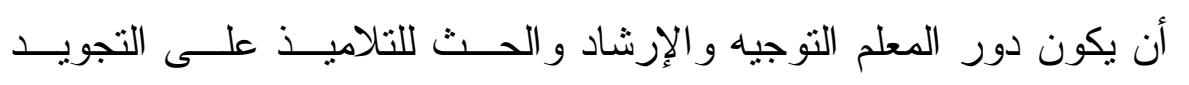

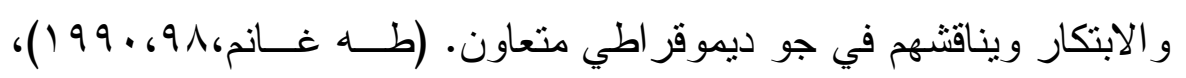

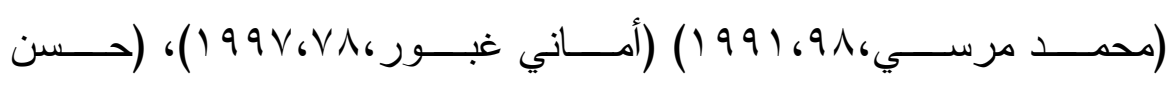

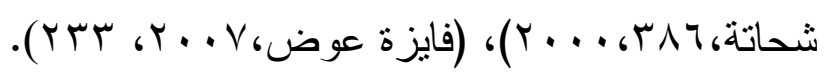


0- معوقات الأنشطة اللغوية:

أرجع العديد من التزبويين هذه المعوقات إلى عدد من الأسباب، هي علــى النحـــ التالي:

$$
\text { • ازدياد كثافة الفصول الدر اسية. }
$$

• قلة نتوع الأنشطة داخل الفصل بالقدر الذي يرضي ميول التلاميذ.

$$
\text { • عدم وجود خطة ذات أهداف محددة للنشاط. }
$$

• فلسفة الأنشطة اللغوية، و أهميتها غير و اضحة لاى المتعلمين.

$$
\text { • افتقاد المعلم للمهار ات اللازمة لممارسة هذه الأنشطة. }
$$

• خلو منهج اللغة العربية من أي إثنارة - تلميحا أو تصريحا - إلــى كيفيــة

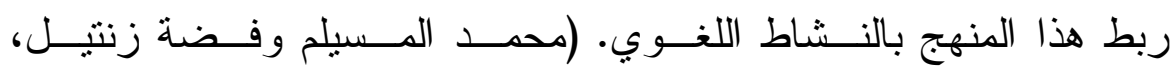

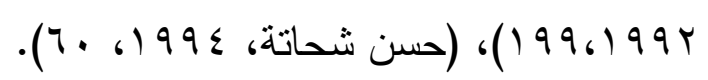

ثنانيا - التر اكيب النحوية:

1 - مفهوم التر اكيب النحوية:

أ- التركيب لغة :هو مصدر للفعل (ركب)، و المصدر يدل على الحدث مجــردا مــن

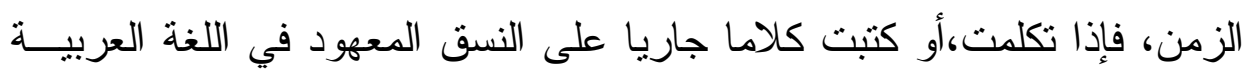

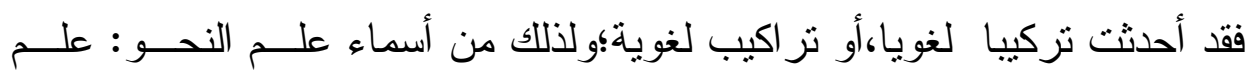

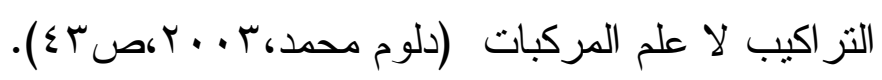

ب- التركيب اصطلاحا :أما في اصطلاح علماء النحو فيعرف التركيب بأنه:اجتمــاع

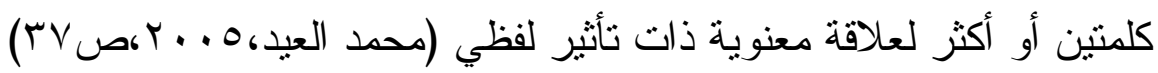


وتعرف الباحثة مفهوم التزراكيب النحوية إجرائيا: قــدرة طــلاب الــصف الأول الثانوي العام على بناء الكلمات، وصياغة تز اكيبها، وضبط أجز ائها، بحيث تعطـي معنى مفهو ما وو اضحا.

r - أهداف تدريس التر اكيب و القواعد النحوية:

لاثثك أن النحو العربي يحظى بمكانة بالغة في اللغة العربية؛ نظر الأنــه وســيلة

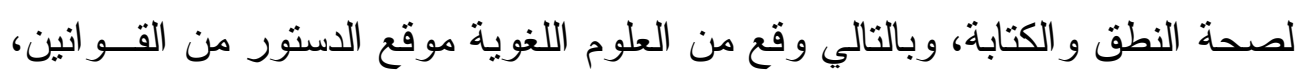

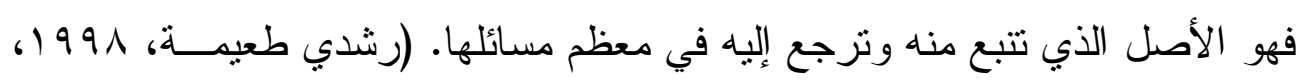
ص (7) إن تدريس النحو يهدف إلى: فهم الجملة، وبنائها لتأدية المعنــى، وتــأليف الكــلام

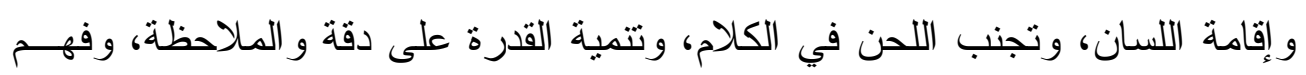

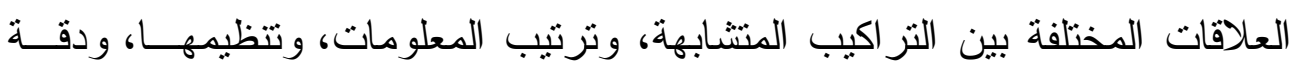
التفكير ، وتتمية ثروة المتعلم اللغوية، وزيادة معلوماته عن طريق الأمثلة، و الثو اهد

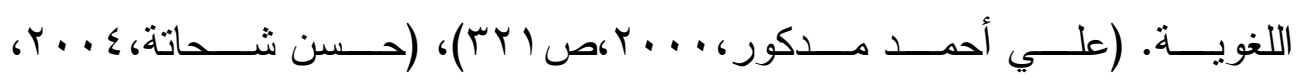

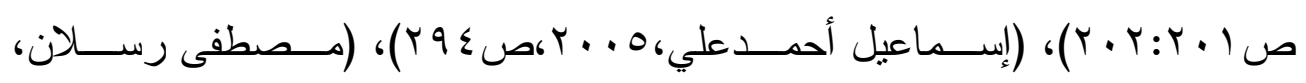

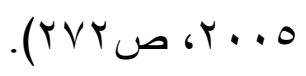

r- أهمية تدريس التراكيب والقواعد النحوية: لا شك أن القو اعد النحوية لبست غاية مقصودة لذاتها، بل لتعويد الطلاب على دقة الملاحظة، و المو ازنة، و الحكم، وتكون في نفوسهم الذوق الأدبي؛ لأن وظيفتها تحليل

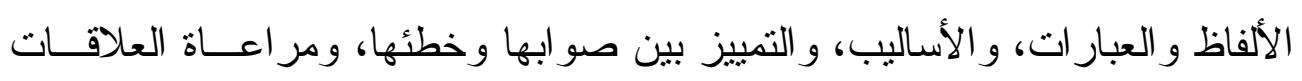

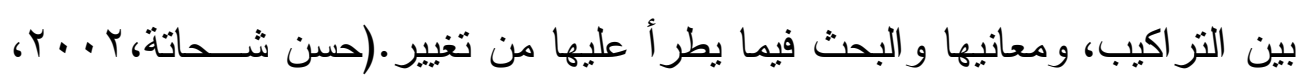

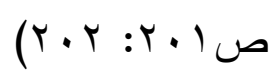

وللنحو الأهمية الكبرى في الاستماعهو التعبير السليم شفهيا، أو كتابيا، وفـي فهـم المقروء فالإعر اب في النحو يوضح المعنى ويبينه، وما مصطلح الإعراب إلا دلالة 
على البيان و الوضوح و لا شك أن القو اعد النحوية تعين على استخدام اللغة استخداما صحيحا في الحديث و القر اعة و الكتابة، فهي وسيلة لعصدة اللسان من الوقــوع فــي

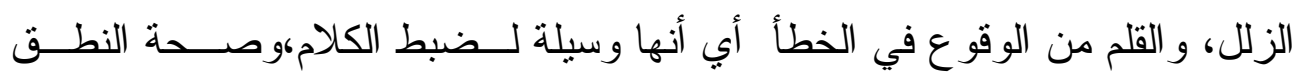

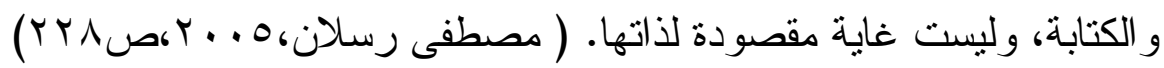
ع - مهار ات التر اكيب النحوية:

إن للمهار ات النحوية تأثير ا كبير ا في تطوير مهار ات القر اءة في سن مبكرة لــدى المتعلمين(Muter, Valerie, 2004, 665) ، و الوقوف علــى جو انــب القـــوة، أو الضعف في أدائهم، ومعرفة مدى مر اعاتهم، وللأساليب، و الإجر اءات التي تتمي تلك

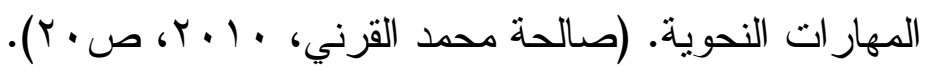

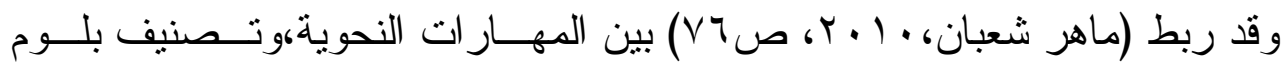
للأهداف المعرفية في مهار ات:الفهم النحــوي، و التــصنيف النحــوي، و الاســتنتاج النحوي، و التحليل و التفسير ، و التطبيق، و الحكم.

\section{ه - صعوبات تدريس القواعد النحوية:}

بالر غم من أهمية در اسة القو اعد النحوية إلا أن الواقع يشير إلى أنها لا تز ال تمثــلـ صعوبة في منهج اللغــة العربيــة، ويعكـسها ضـــف مـستوى الطــلاب فـي تحصيل،و استيعاب القو اعد النحوية وتدني مستوي أدائهم اللغــوي تحـــثنا، وكتابــة، وتتضتح مظاهر الضعف في كثرة الأخطاء النحوية في تعبير ات الطلاب، وتحــثنه.

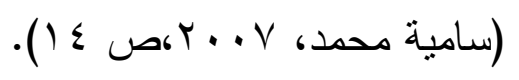

كما أن المدرسين يلمسون ضجر ا، وكر ها من تلاميذهم لمادة النحو، ومعانــاة فــي الإحاطة بالقو اعد التي تمكنهم من الإجابــة عـن التطبيةــات النحويــة الـشفوية،

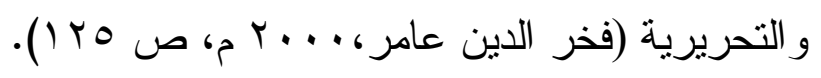


لذا سنحاول أن نتطرق إلى بعض هذه الصعوبات حسب اطــلاع الباحثــة عـــى بعض الكتب و الار اسات السابقة:

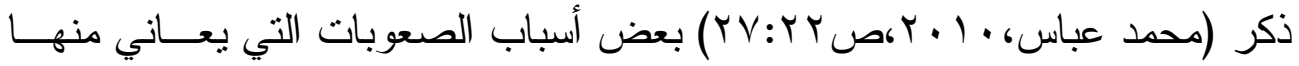
التلاميذ في القو اعد النحوية، وهي كالتالي: 1- البعد عن السليقة اللغوية. r - كثرة القو اعد النحوية، وتشعب تفاصيلها. r- عدم توظيف القو اعد النحوية في الحياة العامة.

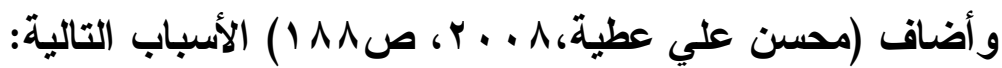
1 - عدم ربط القو اعد النحوية بالمعنى، و الاهتمام بالثكل. r - شيوع العامية بين أوساط الطلبة، و المدرسين. r- الابتعاد عن الوظيفية في تدريس القو اعد النحوية. ثالثا- مهار ات التفكير العلبا في النحو: مفهومها، أهميتها، وتصنيفاتها: تعد مهار ات التقكير العليا من المهار ات الأساسية في النحو العربي؛ و انطلاقاً مـن هذا الأمر فإن الباحثة ستتناول الجو انب التالية:

(1) مفهوم مهارات التفكير العليا: بأنها عمليات معرفية وأداءات (مهار ات) معرفية تتضمن المشاركة الجادة في صناعة القرار سو اء أكان هذا في ضو هء ما تؤديه أو ما ما مات

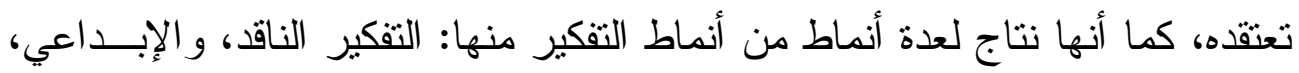
و التفكير البنائي، و أنها في أصلها ترجع إلى تصنيف بلــوم للــستويات المعرفيــة .(Robertson, 2005: 16)

في ضوء العرض السابق لمفهوم مهار ات التفكير العليا تعرفها الباحثة إجر ائياً فـي هذا البحث بأنها مجموعة من الأداءات العقلية المحددة، التي يوظفها طلاب الــصف 
الأول الثانوي العام عند تعلمهم لمقرر النحو العربي، وتقاس هذه الأداءات من خلال اختبار مهار ات التفكير العليا في النحو العربي الذي سبعد لهذا الخرض. r) أهمية مهار ات التفكير العليا: تبدو أهمية مهار ات التفكير العليا فيما تحققه من فو ائد للمتعلم كما يلي:

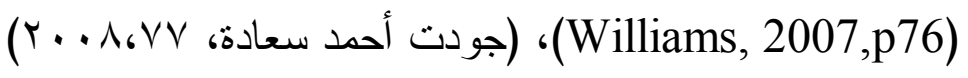

$$
\begin{aligned}
& \text { أولاً - أهميتها للطنلاب: }
\end{aligned}
$$

* مساعدة الطلاب في النظر إلى القضايا المختلفة من وجهات نظر الآخرين. * تقييم آر اء الآخرين في مو اقف كثيرة، و الحكم عليها بنوع و اضح من الدقة. * الإلمام بكيفية التعلم، وبالطرق و الوسائل التي تدعمه. ثانيا - أهميتها للمعلمين:

* مساعدتهم في الإلمام بمختلف أنماط التعلم، ومر اعاة ذلك في العملية التعليمية. * زيادة الدافعية و النشاط و الحيوية لدى المعلمين. * جعل عملية التدريس عملية تتسم بالإثارة و المشاركة. في ضوء ما سبق تتضح أهمية مهار ات التفكير العليا في النحو لطلاب الـصف الأول الثانوي العام فيما يلي:

* تتمي لديهم الفهم الصحيح للتز اكيب اللغوية بناءً على فهم العلاقات الر ابطة بــين

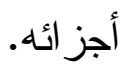

* تدرب الطلاب على تصنيف حالات الاتفاق أو النشابه أو القو اسم المشتركة فـي القاعدة النحوية. * تكسبهم مهارة القياس النحوي الجيد. 
* تتمي لديهم حسن الاستدلال، و التحليل للظو اهر النحوية. * تدربهم على جودة التفسير و التعليل النحوي؛ بما يمكنه من تتمية ملكاتهم العقلية. * تكسبهم مهارة تعميم الحكم النحوي بعد قيامهم بعملية استقر اء ناقص للقاعدة. r) تصنيف مهارات التفكير العليا في النحو العربي: وسعياً من الباحثة لتحديد قائمة

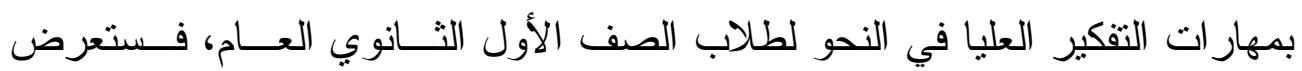
للتصنيفات المختلفة لهذه المهار ات:

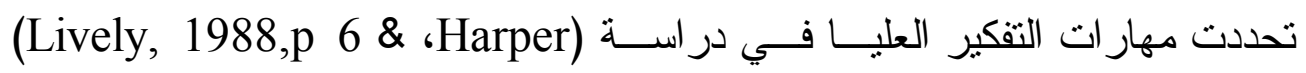
كالآتي:

التصنيف، و التوضيح، وفرض الفروض، و عمل رو ابط، و التعميم، وتحديد علاقات السبب و النتيجة، وتحديد التسلسل، و استخلاص النتائج، و عمل اســتـلالات تتبؤيسـة، وحل المشكلات، و اتخاذ القرار ات، وتقدير القيم، و الإبداع، و الاكتــشاف، و التخيــلـ

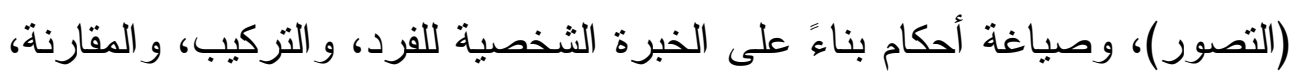
و التناقض، و التفسير ، و الإقناع. وفي در اسة (Price, 2006,p 2): كانت مهار ات التفكير العليا: مهارة التفسير؛ وتتضمن المهار ات الفرعية التالية: التصنيف، وفلك التشفير (التعرف) ونوضيح المعني.

مهارة التحليل؛ وتتضمن: تحديد الأفكار ، وتحديد الحجج، وتحليل الحجج. مهارة التقويم؛ وتتنمل على: تقويم المتطلبات، وتقويم الحجج. مهارة الاستتناج؛ وتحوي: استقصاء الأدلة، وتخمين البدائل، و اسـتخلاص النتائج. 
مهارة الشرح؛ وتتنمل على: تحديد النتائج، وتوضيح الإجراءات، وعرض الحجج. مهارة التظيم الأتي؛ وتتضمن: الفحص الذاتي، و التصحيح الذاتي. أما عن مهار ات التفكير العليا في النحو العربي، فقد قـدم (حسـني عبــد البــاري،

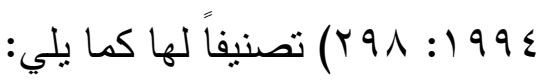

• الملاحظة؛ وتتضمن: ملاحظة اختلاف النطق باختلاف المواقع، ملاحظـــة التزتيب بين عناصر التركيب، ملاحظة اختلاف البدايات فـي مجموعـات التز اكيب.

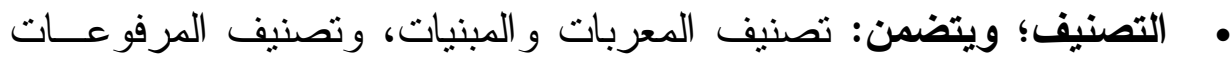
و المنصوبات، و المجرور ات، وتصنيف أنواع الجمـل، وتـــنـف أبــواب التز اكيب.

• التجريد؛ ويشمل: تجريد أبو اب التزكيب، وتجريد مفاهيم التركيب، وتجريــــ أصل القاعدة، وظهور فكرة العدول عن أصل القاعدة.

• التحليل الإعر ابي؛ ويحوي: ملاحظة الكلمات في الجملة، و الغــوص فيمــــا

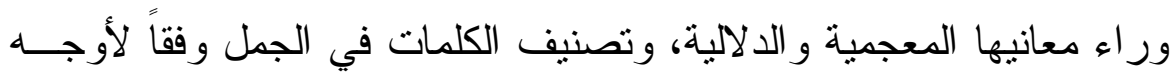

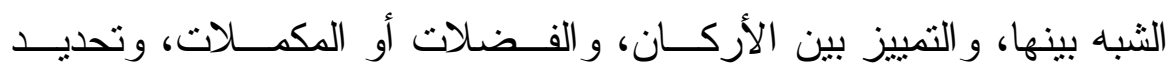
الوظائف النحوية، و التدليل على صحة الاســتتتاجات الـسـابقة، واســتنتاج علامات الإعر اب لكل حكم نحوي، و الربط بين التركيب الو احد وغيره مــن التز اكيب السابقة عليه و التالية لها، وتحديد القرينة النحوية. كما أضاف (صلاح الدين مجاور، 997 199 99) عدداً من مهار ات التفكير العليا في النحو كما يلي: - n * التمبيز بين أنو اع الكلمات. * 
* التمييز بين أنو اع الجمل (اسمية، أو فحلية). * تمبيز مكونات الجملة الفعلية. * تمييز مكونات الجملة الاسمية. * تمييز الجملة من مكماتها. * تعرف مو اقع الجملة وعلاقتها بما قبلها وما بعدها. * تحديد وظيفة الكلمة في الجملة. * تحديد وظيفة الفعل و الاسم و الحرف في الجملة. في ضوء العرض السابق لتصنيف مهار ات التفكير العليا بصفة عامة، ومهــار ات التفكير العليا في النحو العربي بصفة خاصة فقد توصلت الباحثــة لمجموعــة مــن

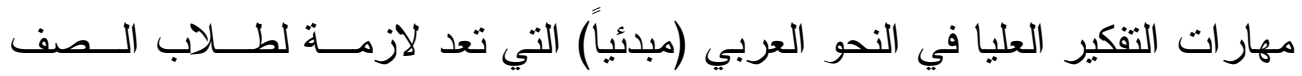
الأول الثانوي العام مثل: مهار ات الفهم النحوي، و التصنيف، ومهار ات الاســتنتاج، و التحليل، و التعليل، و الضبط و الإعر اب؛ تمهيداً لعرضها على الخبر اء و المحكمـين ولين لإقر ار ها. إجراعات البحث: أولا: إعداد اختبرا القواعد النحوية في تدريس قواعد النحو: تم إعداد اختبار القو اعد النحوية وفق ثناث مر احل هي: المرحلة الأولى: التخطيط،و إعداد الاختبار ،وتمت وفق الخطو ات التالية: تحديد الهذف من الاختبار:

استهدف هذا الاختبار قياس قدرة طالبات الصف الأول الثانوي العـام (عينــة الدر اسة) على إتقان مهار ات القو اعد النحوية؛ وذللك لتحسين مستو اهن في قو اعد النحو.

تحديد مهارات القواعد النحوية التي يقيسها الاختبار: 
وتم تحديدها من خلال الرجوع إلى الدر اسات السابقة، و الإطار النظري للدر اســة، وبعض اختبار ات القو اعد النحوية المختلفة في مجال تدريس اللغة العربية، وقد تــــ

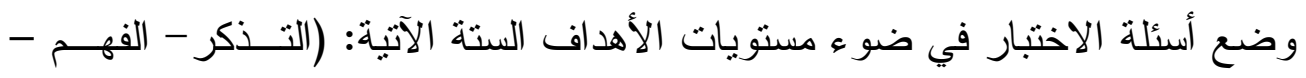

$$
\begin{aligned}
& \text { التطبيق - التحليل - التركيب- التقويم) } \\
& \text { إعداد الصورة الأولية للاختبار: }
\end{aligned}
$$

أعدت الباحثة عددا من الأسئلة في مستوى طالبات الصف الأول الثانوي العام؛كي

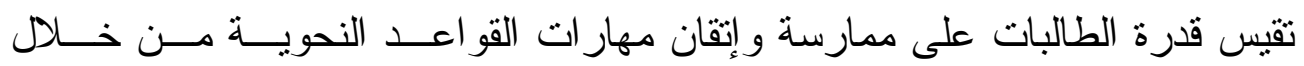
إجابتهن على الأسئلة، وتم إعداد الصورة الأولية للاختبار كو التي روعي فيها مايلي: ا - من حيث الشكل:

مناسبة الأسئلة لمستوى الطالبات.

وضوح الأسئلة،و المطلوب من السؤ ال بالضبط.

صباغة تعليمات الاختبار بحيث تكون و اضحة،ودقيقة.

r - rن حيث المضمون:

• إجابة أسئلة الاختيار من متعدد.

إجابة أسئلة معينة ذات مطلوب محدد.

الإجابة على أسئلة موضوعية، ومقالية تتمي مهار ات القو اعد النحوية.

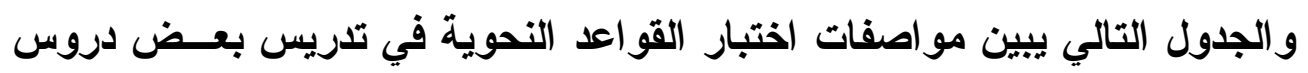
النحو على النحو التالي: 
جدول (1) مواصفات اختبار القواعد النحوية في تدريس بعض دروس النحو

\begin{tabular}{|c|c|c|c|c|c|c|c|c|}
\hline \multirow{2}{*}{ النسبة } & \multirow{2}{*}{ عدد الاسئلة } & \multicolumn{6}{|c|}{ مستويات الاهد(ف } & \multirow{2}{*}{ موضوعات } \\
\hline & & تقويم & تزكيب & تحليل & تطبيق & فهم & تلغكر & \\
\hline \multirow[b]{2}{*}{$\cdot, \wedge$} & \multirow[b]{2}{*}{0} & رقم & رقم & رقم & رقم & رقم & رقم & \multirow{2}{*}{ وملحقاتة } \\
\hline & & $1 \mathrm{~V}$ & $1 \varepsilon$ & r & 11 & $\Lambda$ & - & \\
\hline \multirow[b]{2}{*}{$\cdot, \wedge$} & \multirow[b]{2}{*}{0} & رقم & رقم & رقم & رقم & رقم & رقم & \multirow{2}{*}{ جمع المذكر } \\
\hline & & rו & - & Ir & 1. & 11 & 1 & \\
\hline \multirow[b]{2}{*}{$\cdot, \wedge$} & \multirow[b]{2}{*}{0} & رقم & رقم & رقم & رقم & رقم & رقم & \multirow{2}{*}{ جمع المؤنث } \\
\hline & & 7 & 17 & V & $\varepsilon$ & - & 19 & \\
\hline \multirow{3}{*}{$\cdot, \wedge$} & \multirow{3}{*}{0} & رقم & رقم & رق & رقم & رقم & رقم & \multirow{3}{*}{ إلى إلىاد الأفعال } \\
\hline & & 9 & r & - & 10 & 0 & $r$. & \\
\hline & & & & & & & & \\
\hline
\end{tabular}

\section{تحديد طريقة ثصحيح الاختبار:}

جدول (Y) مفتاح تصحيح اختبار القو اعد النحوية في تلريس بعض دروس النحو

\begin{tabular}{|c|c|c|c|}
\hline مجموع الارجات الكلي لأسئلة & درجة كل & عددأسئلة الاختبار & مستوياث \\
\hline 10 & 0 & r & تذكر \\
\hline 10 & 0 & r & فهم \\
\hline$r$. & 0 & $\varepsilon$ & تطبيق \\
\hline 10 & 0 & r & تحليل \\
\hline 10 & 0 & $r$ & تزكيب \\
\hline$r$. & 0 & $\varepsilon$ & تقويم \\
\hline
\end{tabular}

المرحلة الثانية: ضبط الاختبار 
بعد صياغة أسئلة الاختبار ، وتعليماته، وتحديد طريقة تصحيحه، ونموذج للإجابــة عليه، تم ضبط الاختبار من خلال: 1- التأكد من صدق الاختبار:

أ- صدق المحتوى: وقد اعثمد على الصدق المنطقي في تحديده،يث روعي أثنــاء بناء الاختبار تمثيله لمهار ات القو اعد النحوية المر اد تتميتها من خلل البرنــامج فقط، دون التطرق إلى مهار ات أخرى. ب- صدق المحكمين: للتحقق من صدق الاختبار تم عرضه على مجموعــة مــن

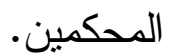
ج - طريقة معامل الاتساق الاخلي: ا-حساب معامل الارتباط بين درجات كل مستوى من مستويات الأهداف،ودرجــة الاختبار ككل التي حصل عليها من الدراسة الاســتطلاعية، وقــد اســتخدمت الباحثة في إيجاد معاملات الارتباط برنامج (spas) وكانت معاملات الارتبــاط كما يوضحها الجدول التالي:

جدول (ب) مصفوفة الارتباط بين درجات الموضوعات بالدرجة الكلية لاختبار القواعد التحوية

\begin{tabular}{|c|c|c|c|}
\hline مستوى الدلالة & | معامل الارتباط & الموضوعاث & م \\
\hline$\cdot, \cdot 1$ & $\cdot, 9 r$ & المثتى وملحقاته & 1 \\
\hline$\cdot, \cdot 1$ & $\cdot, \vee \wedge$ & جمع المذكر السالم & $r$ \\
\hline$\cdot, \cdot 1$ & $\cdot, \vee V$ & جمع المؤنث السالم & r \\
\hline$\cdot, \cdot 1$ & $\cdot, q r$ & إسناد الأفعال إلى الضمائر & $\varepsilon$ \\
\hline
\end{tabular}

r - إيجاد معاملات السهولة و الصعوبة لمفردات اختبار القو اعد النحوية.

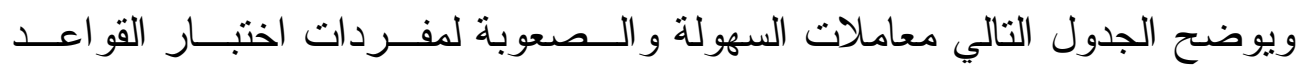
النحوبة 
جدول (ع) معاملات السهولة والصعوبة لمفردات اختبار القواعد التحوية

\begin{tabular}{|c|c|c|c|c|c|c|}
\hline التمبيز & الصعوبة & معامل & المجموع & عدد من أجابوا & عدد من أجابوا & لسؤال \\
\hline$\cdot, r Y$ & سז, • & $\cdot, 7 V$ & r. & 1. & r. & 1 \\
\hline.,$Y \varepsilon$ & 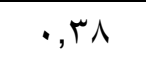 & $\cdot, 7 r$ & r. & 1. & $r$. & $r$ \\
\hline., ro &., 0. &., 0. & r. & 10 & 10 & r \\
\hline$\cdot, Y Y$ & سז, • & $\cdot, 7 V$ & r. & 1. & $r$. & $\varepsilon$ \\
\hline.,$Y \varepsilon$ & $\cdot, \varepsilon$. & $\cdot, 7$. & r. & 14 & 11 & 0 \\
\hline מז, & $\cdot, r V$ & מד, י & r. & 11 & 19 & 7 \\
\hline$\cdot, Y Y$ & سז, • & $\cdot, 7 V$ & r. & 1. & $r$. & V \\
\hline ., ro & $\cdot, \varepsilon r$ &., $0 \mathrm{~V}$ & r. & M & IV & $\Lambda$ \\
\hline$\cdot, Y Y$ & سז, • & $\cdot, 7 V$ & r. & 1. & $r$. & 9 \\
\hline$\cdot$, ro & $\cdot, \varepsilon V$ & י & r. & 1. & $r$. & 1. \\
\hline$\cdot, r \varepsilon$ & $\cdot, \varepsilon$. & $\cdot, 7$ & r. & ir & 11 & 11 \\
\hline$\cdot$, ro & r & $\cdot, 0 \mathrm{~V}$ & r. & r & IV & IT \\
\hline$\cdot, r Y$ & חז, • & $\cdot, 7 V$ & r. & 1. & $r$. & M \\
\hline.,$Y \varepsilon$ & $\cdot, \varepsilon$. & $\cdot, 7$. & r. & 14 & 11 & $1 \varepsilon$ \\
\hline$\cdot, r \leq$ & $\cdot, \leq$. & $\cdot, 7$. & r. & 14 & 11 & 10 \\
\hline., ro &., 0 & $\cdot, 0$. & r. & 10 & 10 & 17 \\
\hline$\cdot, Y Y$ & سז, • & $\cdot, 7 V$ & r. & 1. & $r$. & IV \\
\hline$\cdot, r \leqslant$ & $\bullet, \varepsilon$. & $\cdot, 7$. & r. & 14 & 11 & 11 \\
\hline$\cdot, Y Y$ & سז, • & $\cdot, 7 V$ & r. & 1. & $r$. & 19 \\
\hline . , Yo &., 0 . &., 0 & r. & 10 & 10 & $r$. \\
\hline$\cdot, Y Y$ & سז, • & $\cdot, 7 V$ & r. & 1. & $r$. & YI \\
\hline$\cdot, r \varepsilon$ & $\cdot, \varepsilon$. &., 7. & r. & Ir & 11 & rr \\
\hline$\cdot, r \leq$ & $\bullet, \leq$. & $\cdot, 7$ & r. & 14 & 11 & r \\
\hline$\cdot, r Y$ & سז, • & $\cdot, 7 V$ & r. & 1. & $r$. & $r \varepsilon$ \\
\hline ., Yo &., 0. &., 0. & r. & 10 & 10 & ro \\
\hline$\cdot, r \leq$ & $\bullet, \varepsilon$. & $\cdot, 7$. & r. & Ir & 11 & $r T$ \\
\hline.,$Y_{0}$ &., 0. &., 0. & r. & 10 & 10 & $r V$ \\
\hline
\end{tabular}


العدد الحادي عشر ... الجززء الثالث

\begin{tabular}{|c|c|c|c|c|c|c|}
\hline التميزيز & الصعوبة معامل & السهولة & المجموع & عدد من أجابوا & عدد من أجابوا & السؤال \\
\hline$\cdot, r \leq$ & $\cdot, \varepsilon$. & $\cdot, 7$. & $r$. & Ir & 11 & $r \wedge$ \\
\hline$\cdot, r Y$ & س r, • & $\cdot, T V$ & $r$. & 1. & $r$. & rq \\
\hline$\cdot, r_{0}$ & $\cdot, \leqslant \vee$ & . OT & $r$. & 1. & $r$. & $r$. \\
\hline
\end{tabular}

يتضح من الجداول السابقة أن معاملات الاتساق للأسئلة المكونة لاختبار القواعـد النحوية في تدريس النحو دالة إحصائيا مما تدل على صدق الاختبار .

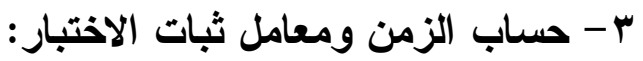

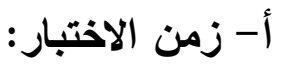

لحساب زمن الاختبار تم أخذ متوسط زمن إجابة العينة الاستطلاعية على مفردات الاختبار ، ولحساب المتوسط تم جمع زمن إجابة كل تلميذ، ويقسم على العدد الكلـى للتلاميذ فكان الزمن اللززم للإجابة عن الاختبار ( • ) دقيقة.

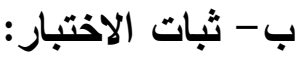

اعتمدت الباحثة في حــساب معامـلـل ثبــات الاختبــار الحــالي علــى معـــــادلة

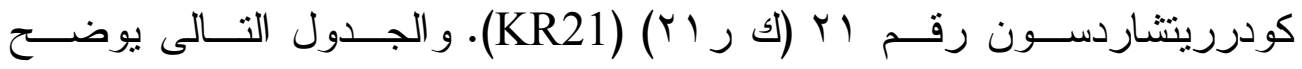
معامل ثبات الاختبار (حيث إن الدرجة النهائية للاختبار هى . . 1) جدول (•) ثبات اختبار القواعد النحوية في تدريس النحو

\begin{tabular}{|c|c|c|c|c|}
\hline معامل الثبات & 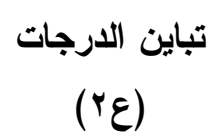 & 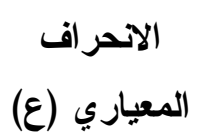 & متوسط الدرجات (م) & للاختبار (ن) الدرجة \\
\hline •, 94 & $187, .9$ & IT, & 79,17 & $1 \ldots$ \\
\hline
\end{tabular}




\section{ثانيا: إعداد قائمة بمهيار ات التفكير العليا:}

قامت الباحثة بحصر مهار ات التفكير العليا في النحو اللازمة لطلاب الـصف الأول الثانوي العام، وتم الاستعانة بالعديد من المصادر لاشتقاق هذه المهار ات وهي: ا. الدر اسات و البحوث السابقة العربية و الأجنبية المرتبطة بالمهار ات النحوية. r. الأدبيات المتصلة بمهار ات التفكير العليا في النحو العربي. وقامت الباحثة بإعداد القائمة لتتضمن ست مهار ات عليا للتفكير النحوي وهي: مستوى الفهم النحوي، و التصنيف النحوي، و التحليل، و التقسير، و التطبيق، و أخيــراً الضبط النحوي، وتم وضعها في قائمة حيث وضعت المهار ات في الخانـــة الأولـى من القائمة، وبجو ارها عدة خانات منها: خانتان لمدى اتساق المهارة الفرعيــة مــع المهارة الرئيسة التي تتنمي إليها و أخريان لمدى مناسبة هــــهـ المهــار ات لطــلاب

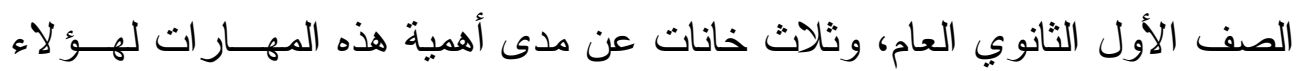

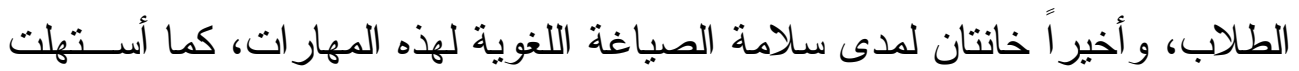
الباحثة هذه القائمة بمقدمة توضح الهدف من البحث، وكذلك الهدف منها، فضلاً عن التعريف الإجر ائي لمهار ات التفكير العليا في النحو، و المصادر التي استتد ت عليها الباحثة في اشتقاق هذه القائمة. أ- تحكيم القائمة: تم عرض قائمة مهار ات التفكير العليا في النحــو العربــي علـى عشرين محكماً من أساتذة المناهج وطرق التذريس، و أساتذة اللغة العربية عامـــة و النحو العربي بصفة خاصة، علاوة على خبر اء الميدان، وطلبت الباحثــة مــن المحكمين إبداء الر أي حول القائمة وذللك بوضع علامة ( ل) بما يعبر عن رأيهـــ في القائمة من حيث:

* اتساق المهار ات الفرعية مع المهارة الرئيسة التي تتدرج تحتها. * مناسبة كل مهارة من هذه المهار ات لطلاب الصف الأول الثانوي العام. 
* سلامة الصياغة اللغوية لهذه المهار ات. * إضافة أو حذف أو تعديل ما يرونه مناسباً لمزيد من ضبط هذه القائمة. ب- حساب الوزن النسبي لمهار ات التفكير العليا في النحو العربي للطلاب: تم حساب الوزن النسبي لمهار ات التفكير العليا في النحو، وتم ذلك من خــله

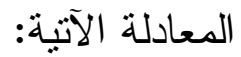

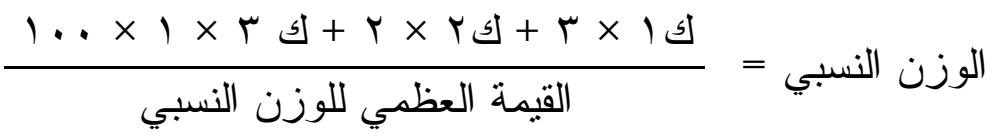

حيث إن القيمة العظمي للوزن النسبي = عدد المحكمين × ب، وذلك للاحتكام إلـى هذه النسب في استبعاد بعض هذه المهار ات، وحددت الباحثة معيار اً لاختيار بعـض منها، وهي المهار ات التي حظيت بنسبة اتفاق بين المحكمين بنـسب تتــر اوح مــن

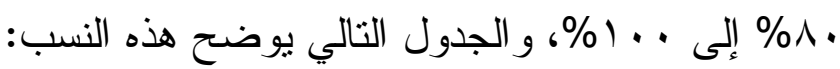

$$
\text { جدول رقق (7) }
$$

\begin{tabular}{|c|c|c|c|c|c|c|}
\hline \multirow[b]{2}{*}{ النسبي \% } & \multirow[b]{2}{*}{ اللقيمة العظمى النسبي } & \multicolumn{3}{|c|}{ درجة أهميتها } & \multirow[b]{2}{*}{ المهارة الرئيسة } & \multirow[t]{2}{*}{ 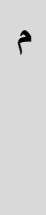 } \\
\hline & & 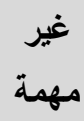 & مهمة & مهمة & & \\
\hline & & & & & \multicolumn{2}{|l|}{ أولاً: مهارات الفهم النحوي: } \\
\hline ヘฯ, ฯ & or & $r$ & r & 10 & لركن الجملة. لطالب للوظيفة النحوية & 1 \\
\hline 91,79 & 00 & 1 & $r$ & 19 & ضبط الكلمات ضبطا صحيحا. & r \\
\hline$\Lambda \wedge, r \mu$ & or & 1 & 0 & $1 \leqslant$ & | تحديد دلاةة بعض المصطلحات & $r$ \\
\hline & & \multicolumn{5}{|c|}{ ثانيا: مهارات التصنيف النحوي: } \\
\hline 1, & $\leqslant 9$ & $r$ & $\bullet$ & Ir & | تحديد أوجه الثبه بين التراكيب & $\varepsilon$ \\
\hline
\end{tabular}

الوزن النسبي لمهارات التفكير العليا في النحو العربي لطلاب الصف الأول الثانوي العام 


\begin{tabular}{|c|c|c|c|c|c|c|}
\hline & & \multicolumn{3}{|c|}{ درجة أهميتها } & \multirow[b]{2}{*}{ المهارة الرئيسة } & \multirow[t]{2}{*}{ r } \\
\hline النسبي ا الوزن & اللوزنة النسبي النظمي & غيرة & 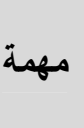 & مها & & \\
\hline 10 & 01 & $r$ & $r$ & $1 \varepsilon$ & تصنيف الكلمــات مـن حيــث & $\bullet$ \\
\hline ヘฯ, ฯ & or & $r$ & r & 10 & 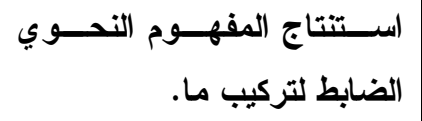 & 9 \\
\hline & & \multicolumn{5}{|c|}{ ثالثا: مهارات التحليل النحوي: } \\
\hline no & 01 & $r$ & $r$ & $1 \varepsilon$ & تحكيل التركيب النحــوي إلــى & $v$ \\
\hline$\Lambda \wedge, r \mu$ & or & $r$ & 1 & 17 & تلاللغيل بعض المشتقات لجذرها & $\wedge$ \\
\hline A. & 01 & 0 & r & $1 \pi$ & تلتليل العلاقات النحويـــة فــي & 9 \\
\hline & & \multicolumn{5}{|c|}{ رابعا: مهارات التفسير النحوي: } \\
\hline$\Lambda \wedge, r \mu$ & or & r & $r$ & 10 & تلبعض التر اكيب النحوية. & 1. \\
\hline$\wedge$. & $\varepsilon \wedge$ & $\varepsilon$ & $\varepsilon$ & ir & تفعير عدول بعض التراكيــب & 11 \\
\hline \multirow[t]{2}{*}{$\Lambda}$. & $\varepsilon \wedge$ & $\varepsilon$ & $\varepsilon$ & Ir & تفسيره لأنواع العلل الواردة في & ir \\
\hline & & \multicolumn{5}{|c|}{ خامسا: مهارات التطبيق النحوي: } \\
\hline ( & 04 & 1 & r & IV & تركيب نحويل التركيب آنـــوي إلـــى & ir \\
\hline ヘฯ, & or & $r$ & r & 10 & تصويل بعض الأبنية أبنية الــصرفية & $1 \leqslant$ \\
\hline$\Lambda \wedge, r \mu$ & or & 1 & $\bullet$ & $1 \leqslant$ & تشبيق بعض الأساليب النحوية & 10 \\
\hline & & \multicolumn{5}{|c|}{ سادسا: مهارات الضبط النحوي: } \\
\hline
\end{tabular}




\begin{tabular}{|c|c|c|c|c|c|c|}
\hline & & \multicolumn{3}{|c|}{ درجة أهميتها } & \multirow[b]{2}{*}{ المهارة الرئيسة } & \multirow[t]{2}{*}{ b } \\
\hline النسبي \% الوزن & اللوزيمة العظمى النسبي & 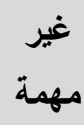 & مهمة & مهمة & & \\
\hline 9. & $0 \leqslant$ & $r$ & r & 17 & في التركيب الإعراب لبعض الكلمات & 17 \\
\hline 10 & 01 & $r$ & 0 & ir & الصرفية. على صحة بعض البنــي & iv \\
\hline$\Lambda \Lambda, r \mu$ & or & $r$ & $r$ & 10 & تصويب بعض التراكيب النحوية & 11 \\
\hline
\end{tabular}

ثالثا: بناء اختبار مهار ات التفكير العليا لطلاب الصف الأول الثانوي العام:

استهدف هذا الاختبار قياس مهار ات التفكير العليا في النحو العربي،وقد نم بناء هذا الاختبار لقياس اثثتين وعشرين مهارة، وهي المهار ات التي تز اوحت نـسبتها مــن

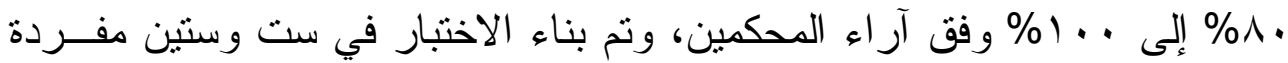

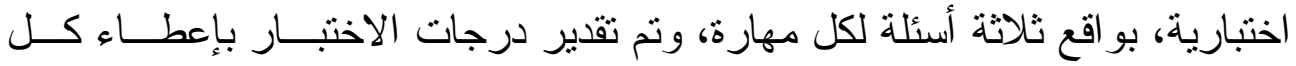

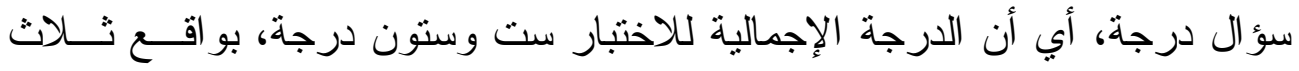

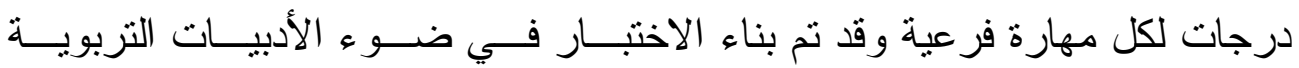
و الدر اسات السابقة، ومقابلة بعض المتخصصين وبالإضـافة إلــى النــسب المئويــة للمهار ات المذكورة آنفا. أ- تحكيم اختبار مهار ات التفكير العليا: عـرض الاختبــار علـى مجموعـــة مــن المحكمين المتخصصين في النحو العربي وطر ائق تدريسه علاوة علــى خبــر اء الميدان؛ لتحديد ما يلي: 
* مناسبة الأسئلة الموضوعة لمهار ات التفكير العليا في النحو العربي * صحة البدائل الاختبارية لكل سؤ ال * سلامة الصياغة اللغوية للأسئلة وللبدائل و أبدى المحكمون آر اءهم في الاختبار كما يلي:

* أثنار بعض المحكمين إلى أن بعض الأسئلة وخصوصسا السؤال الخامس عـشر ،

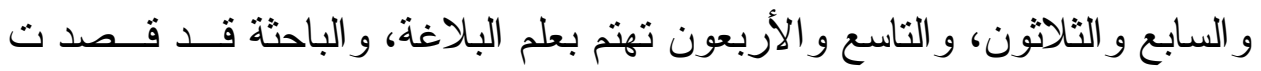

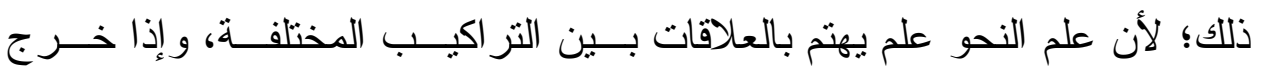
التركيب اللغوي عن المألوف نحويا، خرج لسبب بلاغي وهذا من صميم الدر اسة بهاب النحوية.

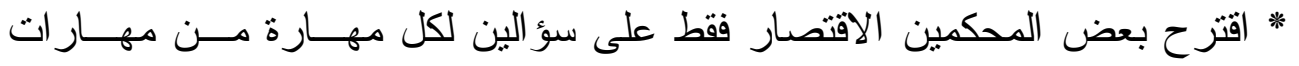
التفكير النحوي، و الباحثة لم تأخذ بهذا الر أي؛ لأنه لو اقتصر على سؤ الين فقـ طـ

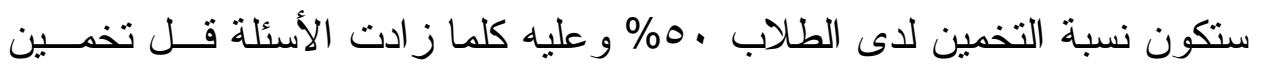
الطلاب لها.

ب- ضبط اختبار مهار ات التفكير العليا في النحو العربي؛لضبط اختبــار مهــار ات التكفير العليا في النحو العربي تم إتباع الآتي:

حساب زمن الاختبار: نم تطبيق الاختبار على مجموعة من طــلاب الــصف الأول

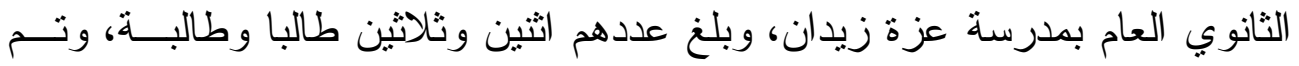

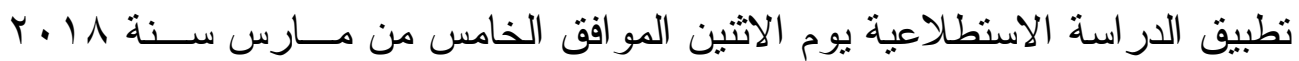
ميلادية، وتم حساب متوسط الزمن للخمسة طلاب الأسرع أداء في الإجابــة عـن النـ اختبار مهار ات التفكير العليا في النحو العربي، وحساب متوسط الــزمن للطــلاب الخمسة الأبطأ في حل الاختبار ، ووجد أن منتسط زمن الاختبار هو (10) دقيقة. 
حساب معامل التمييز لاختبار مهار ات التفكير العليا في النحو العربي: تم حساب معامل القوة التميزية للاختبار من خلا المعادلة التالية:

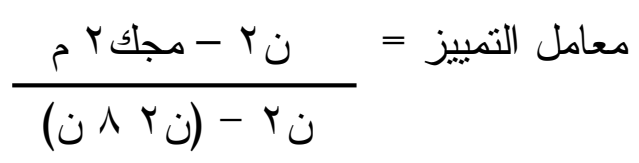$$
\text { حيث إن ن = عدد العينة. }
$$

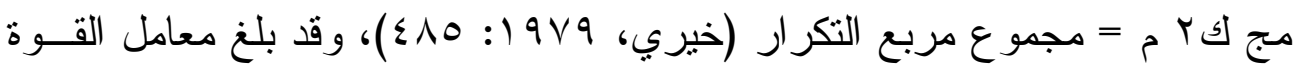
التميزية.. 9 9 هو معامل تمبيز قوي يطمئن على القوة التمييزية للاختبار .

معامل السهولة و الصعوبة لمفردات اختبار مهار ات التفكير العليــا: قامــت الباحثــة

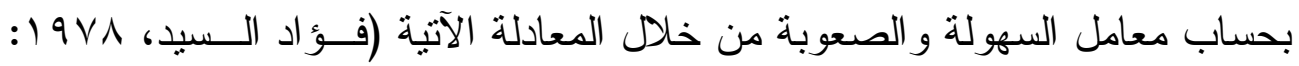
$:(\leqslant \Sigma 9$

$$
\text { معامل الصعوبة = عدد الإجابابات الخطأ الصحيحة + عدد الإجابات الخطأ }
$$

وقد اعتبرت الباحثة المفردات التي يزيد معامل صعوبتها عن..9 مفـردة صــعبة

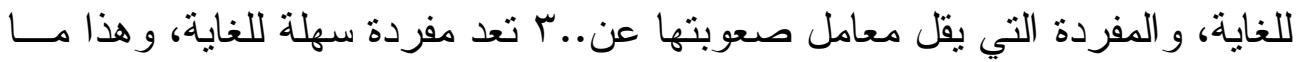
ارتضته بعض الدر اسات منها (عبد الباري عصر ، 9 . . ب). وفي ضــوء حسـساب الباحثة لمعامل السهولة و الصعوبة تم تعديل بعض المفردات وهي: المفردة الأولــي؛ لأنها مفردة سهلة للغاية، وتعديل المفرد التاســعة، و التاســعة عـشرة، و الــسادسة و العشرين، و التاسعة و التثلاثين، و الثامنة و الخمسين؛ لأنها كانت مفردات صعبة وفقا للمعيار الذي ارتضاه الباحث.

حساب ثبات الاختبار: لحساب ثبات الاختبار نم الاستعانة بطريقة التجزئة النصفية لمفردات الاختبار، حيث تكون الاختبار من ست وستين مفردة اختبارية، تم تقسيمهح إلى قسمين: القسم الأول يتضمن المفردات الفردية، و الثتـاني يتـضـمن المفــردات الزوجية، وتم حساب معامل الارتباط بين الدرجتين الفردية و الزوجية مــن خــلد 


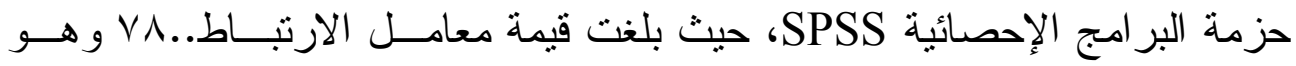
معامل ثبات مرتفع نسبيا لاختبار مهار ات التفكير العليا في النحو العربي. نتائتج البحث، و التوصيات، و المقترحات اختبار صحة فروض البحث: أولاً - اختبار صحة الفرض الأول: بالنسبة للفرض الأول من فروض البحث، والذي ينص على ما يلي: " توجد فروق ذا دلالة إحصائية بين متوسطي درجات تلاميذ المجموعة التجريبية فى التطبية لين القبلي والبعدي لاختبار القواعد النحوية لصالح التطبيق البعدي " للتحقق من صحة هذا الفرض قامت الباحثة بحسـساب قيمــة (ت) للمقارنــة بـين متوسطي درجات تلاميذ المجموعة التجريبية فى التطبيقين القبلي والبعدي لاختبار القواعد النحوية ويتضح ذلك من الجدول التالي: (v) جدول

قيمة (ت) ودلالتها الإحصائية للفرق بين منتوسطي درجات تلاميذ المجموعة التجريبية

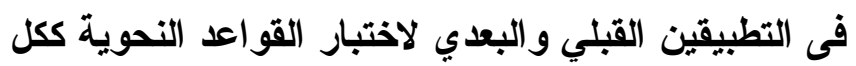

\begin{tabular}{|c|c|c|c|c|c|c|c|}
\hline $\begin{array}{c}\text { حجم التأثير } \\
\text { (d) }\end{array}$ & الإحصائية & قيمة اتمسوبة) & لدرية & الالمعر افياري & المتوسط & العدد & الإلهوبائية البياتات \\
\hline \multirow{2}{*}{$1 \wedge, \leqslant Y$} & \multirow{2}{*}{$\cdot, \cdot 1$} & \multirow{2}{*}{$\leqslant 9,7}$. & \multirow{2}{*}{ rq } & $\varepsilon, 0$. & ro, Tr & $r$. & القبلي \\
\hline & & & & T,人 & $V \wedge, \cdot r$ & $r$. & البعدي \\
\hline
\end{tabular}

يتضح من الجدول السابق أن قيمة (ت) المحسوبة ( • 7, ؟ )،وقيمة (ت) الجدوليــة

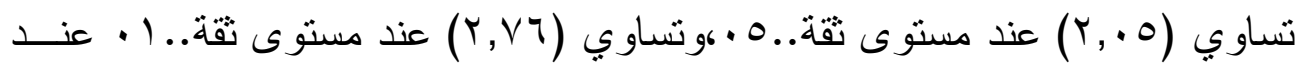




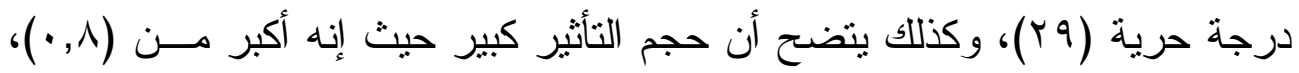

$$
\text { و هو بيساوي (1), (1) ). }
$$

مدا سبق يتضح أن قيمة (ت) المحسوبة أكبر من قيمة (ت) الجدولية؛مما بدل على وجود فرق ذي دلالة إحصائية لصالح التطبيق البعدي، وبذلك تم التحقق من صـــة

الفرض الأول.

\section{ثانيا - اختبار صحة الفرض الثاني:}

الذي ينص على وجود فروق ذات دلالة إحصائية بين متوسطي درجــات طــلاب الصف الأول الثانوي العام عند مستوى..0. في اختبار مهار ات التفكير العليا فـي النحو العربي في التطبيقين القبلي و البعدي لصالح التطبيق البعدي، وتم التحقق مــن اختبار صحة هذه الفرضية، بحساب اختبار (ت) لمجمو عتين مرتبطنين ومنساويتين من خلال حزمة البر امج الإحصائية SPSS، و الجدول التالي يوضح ذلك:

جدول (1)

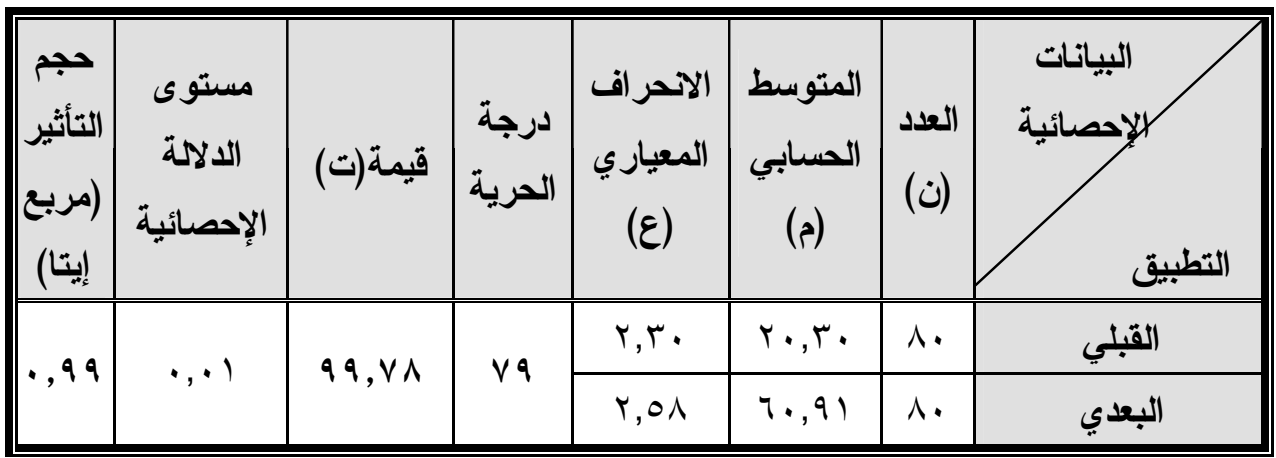

كما قامت الباحثة بحساب مربع إيتا([([[*])؛ لقياس حجم التأثير للبرنـامج مسن خلا المعادلة التالية (أبو حطب وصادق، 199 19: 9 ب \&):

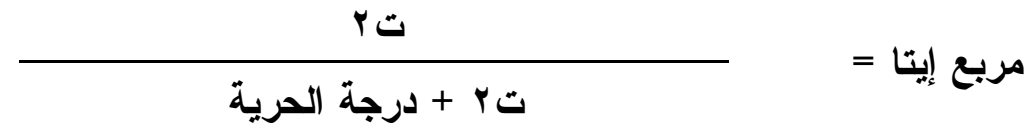


بقر اءة الجدول السابق يتضح وجود فروق ذات دلالة إحصائية عند مسستوى.. 1 . بين متوسطي درجات طلاب الصف الأول الثانوي العام في اختبار مهار ات التفكير العليا في النحو العربي لصالح التطبيق البعدي، وبلغ حجم التأثير (مربع إيتـا)..99 وهو حجم تأثثر مرتفع يدلل على صحة الفرض الثاني. ثالثاً - اختبار صحة الفرض الثالث:

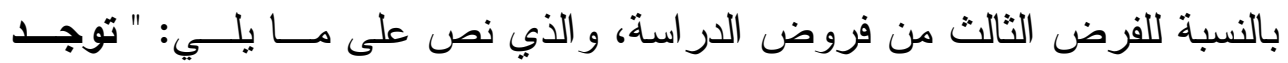
علاقة ارتباطية طردية بين أداء طلاب المجموعة التجريبية في اختبــار التراكيـب النحوية، وأدائهم في اختبار مهارات التفكير العليا".

للتحقق من صحة الفرض قامت الباحثة بحساب معامل الارتبــاط بــين درجــات الطلاب عينة الدراسة فى اختبار التراكيب النحوية،وأدائهم فـي اختبــار مهـــارات

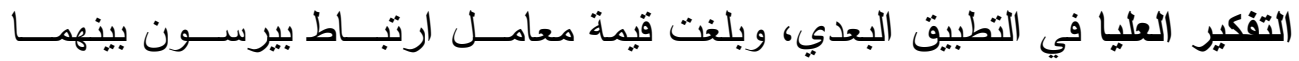
$\cdot(\cdot, 7 r)$ جدول (9) العلاقة بين درجات الطلاب عينة الدراسة فى اختبار التراكيب النحوية،وأدائهم في اختبار مهارات التفكير العليا

\begin{tabular}{|c|c|c|}
\hline اختبار مهار ات التفكير & اختبار التراكيب & \\
\hline$* *, 7 r$ & - & اختبار التراكيب النحوية \\
\hline- & $* *, 7 r$ & اختبار مهارات التفكير العليا \\
\hline
\end{tabular}

مما سبق يتضـح أنه نوجد عــــلاقة طردية بين درجات الطلاب عينة الدراسة في اختبار التراكيب النحوية، وأدائهم في اختبار مهارات التفكير العليا علاقة ارتباطية طردية دالة عند مستوى (1 • , •). يتضح من الجدول السابق أن تحسن مستوى التز اكيب النحوية يؤدى الــى تحسـسن مهار ات التقكير العليا لدى المجموعة التجريبية و العكس. 


\section{توصبات الار اسة:}

در اسة أثز الأنشطة اللغوية اللاصفية في تتمية المهار ات النحوية.

ضرورة توفير أدلة علمية وعملية لكيفية تتمية مهار ات التفكير العليــا فـي النحو العربي لدى طلاب المر احل الدر اسية المختلفة.

\section{مقترحاث الدر اسة:}

فاعلية بعض إستر اتيجيات التفكير المنتعب في تتمية مهار ات التفكير العليــا في النحو العربي لطلاب المر احل التعليمية المختلفة.

برنامج لتتمية عمليات التفكير المصاحبة للتعرف في النحو العربــي وأتــره في تتمية مهار ات التقكير العليا لدى طلاب المر احل الدر اسية المختلفة. 


\section{المراجِي}

صالحة محمد ظافر القرني( • ( • ب) " مدى تمكن معلمات اللغة العربية مسن

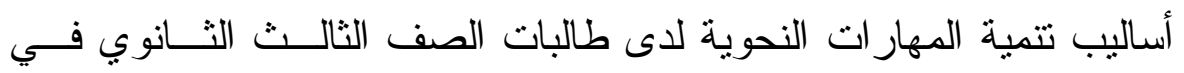
العاصمة المقدة" رسالة ماجستير، كلية التزبية، جامعة أم القرى

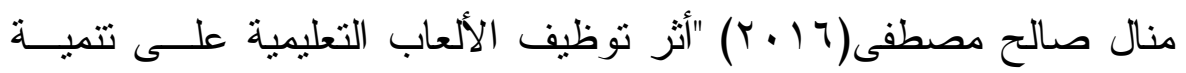
التفكير الاستقر ائي و التفاعل الاجتماعي في النحو العربـي لــدى طالبــات

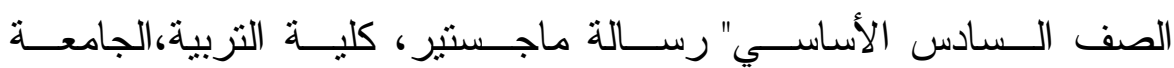
الإسلامية،غزة.

آمال إسماعيل حسن (10 ب ب) "دور المدخل الدلالي في خفض قلق الإعراب

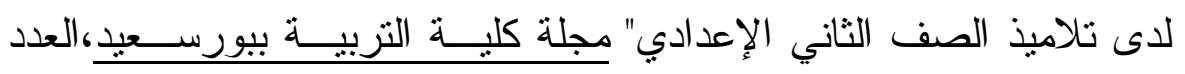
(IV)

حسني عبد الباري عصر(0. ‥ إ) الاتجاهات الحديثة لتدريس اللغة العربية في المرحلتين الإعدادية والثانوية، الإسكندرية، مركز الإسكندرية للكتاب.

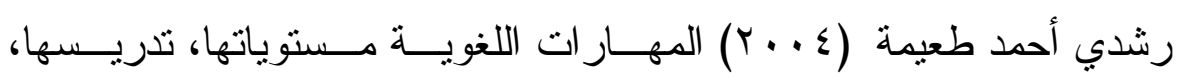
صعوبتها دار الفكر العربي،القاهرة.

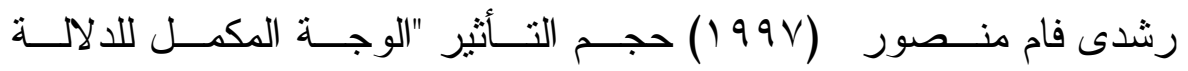
الإحصائية" • المجلة المصرية للار اسات النفسية، المجلد(V) العدد (T ( ). فؤاد البهى السيد (991 (191) علم النفس الإحصائي وقياس العقل البشري، دار القكر العربي، القاهرة. - مبك. محمد صلاح الدين علي مجاور(991 (1) تدريس اللغة العربيــة بالمرحلـــة الابتدائية أسسه وتطبيقاته، الكويت، دار القلم • 


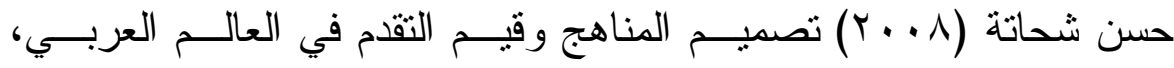
القاهرة، الدار المصرية اللبنانية. فخر الدين عامر ( (. . . ط) طرق التـدريس الخاصة باللغة العربية و التزبية الإسلا مية، طب القاهرة،عالم الكتب. محمد قاســ (T + . r) معايير التفوق اللغوى لدى طلاب التعليم العام وتقويم الأداء اللغوي لطلاب المتفوقين في ضوئها، مجلة كلية التربية بأسيوط مجلد

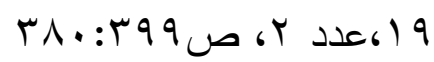

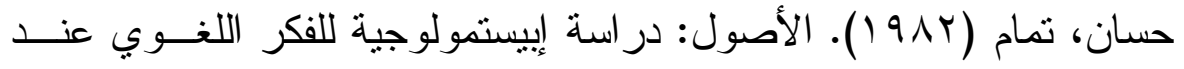
العرب. القاهرة: الهيئة المصرية العامة للكتاب.

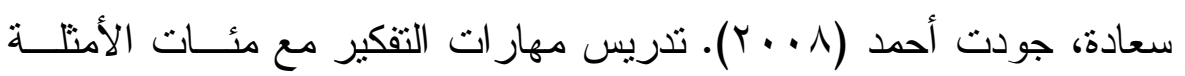
التطبيقية. عمان - الأردن: دار الثروق للطباعة و النشر . ضيف، شوفي (r99 (1)). المدارس النحوية، الطبعة الــسابعة. القــاهرة: دار

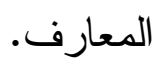

عصر ، حسني عبد الباري (ع99 1). الاتجاهات الحديثــة لتـدريس اللغـــة العربية في المرحلتين الإعدادية و الثانوية. الإســكندرية: المكتـبـ العربـي الحديث للطباعة و النشر .

على، إسماعيل أحمد (0 . . ب). فاعلية مدخل قائم على المعني في تــدريس

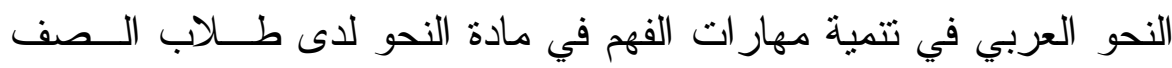
الثالث الإعدادي. رسالة ماجستير (غير منشورة)، كلية التزبية بكفر الـشيخ، جامعة طنطا. - جإن عبد، محمد (ך ץ). أصول النحو العربي. القاهرة: عالم الكتب. مجاور ، محمد صلاح الدين على (99V (1)). در اسة تجريبية لتحديد المهار ات اللغوية في فروع اللغة العربية، الطبعة الثانية. الكويت: دار القلم. 


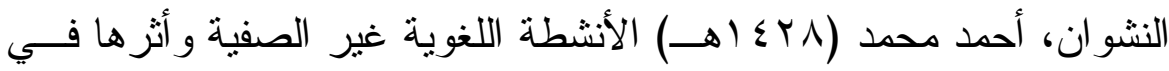
اكتساب المهار ات اللغوية لدى متعلمـــي اللغـــة العربيــة، مجلـــة القــر اءة

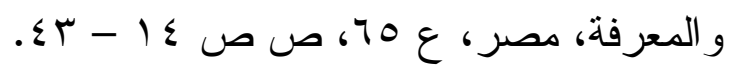

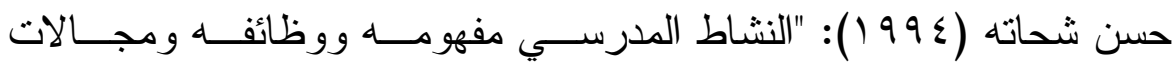
تطبيقه"، القاهرة، الدار المصرية اللبنانية.

سنية الثافعي (ـ99 (1)): "النشاط المدرسي بمدارس التعليم العام بالـسعودية، مجلة التزبية المعاصرة، العدد (سب)، سبتمبر.

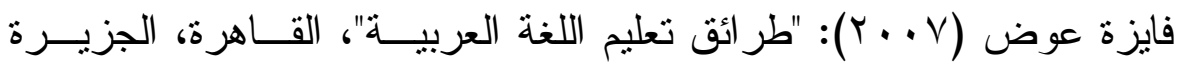
للطباعة و النشر .

محمد المسلم، فضة زننيل (199 (1): "در اسة لمعوقات الأنشطة الابتكاريــة في مدارس التعليم الثانوي في الكويت من وجهة نظر عينــة مـــن النظـــار و الناظر ات"، المجلة التربوية، جامعة الكويت، العدد (ع ب).

محمود السيد (997 (1)): "في طرائـق تــدريس اللغـــة العربيــة"، دمـشقق، منشور ات جامعة دمشق.

- Walker, V. (2001). Make Learning Fun for Preschoolers.Http: $\mathrm{mm}$. Assortment. Come Fun learning - reag.him.

- Harper, Jane \& Lively, Madeleine (1988). We have got the 2.HOTS for foreign languages: Higher order thinking skills Tarrant County Junior College،Educational Resources Information Center

- Peirce, William (2006). Designing rubrics for assessing higher 3-order thinking. Paper Presented at AFACCT, 
Howard Community College ‘Columbia, 13 January, pp. $1-15$.

- Robertson, Charles L.(2005). Development and transfer of 4-higher order thinking skills in pilots. Unpublished Dissertation ‘Capella University.

- Macaluso, Rosalinda (2006) through the looking glass": Grammatical skills as a critical component to successful reading comprehension Unpublished Dissertation Johan's University, New York. 